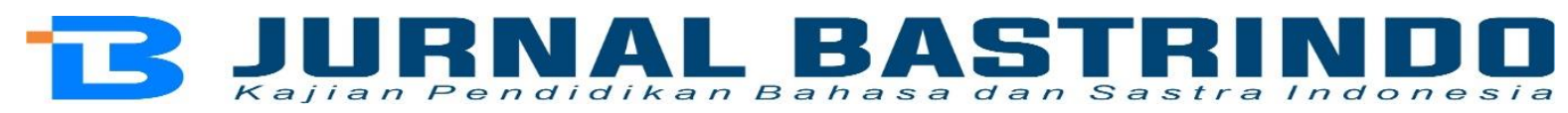

\title{
Penyusunan Rencana Pelaksanaan Pembelajaran (RPP) Daring Teks Prosedur oleh Guru Kelas VII SMP se-Kota Mataram Selama Pandemi Covid-19
}

\author{
I Putu Lanang Wijidyatmikal; Sapiin²; Siti Rohana Hariana Intiana ${ }^{3}$ \\ 1,2,3Pendidikan Bahasa dan Sastra Indonesia, FKIP Universitas Mataram
}

Posel: pandeputulanangwijidyatmika9@gmail.com

\begin{abstract}
Abstrak: Penelitian ini bertujuan untuk mengetahui penyusunan Rencana Pelaksanaan Pembelajaran (RPP) daring teks prosedur oleh guru kelas VII SMP se-Kota Mataram selama pandemi covid-19. Metode penelitian ini adalah kualitatif deskripftif. Data-data yang diperoleh berupa implementasi tujuan, langkah-langkah bagian kegiatan inti, dan penilaian RPP daring teks prosedur di enam sekolah. Dalam penelitian ini ditemukan bahwa RPP daring teks prosedur SMP Negeri 3 Mataram, SMP Negeri 4 Mataram, SMP Negeri 5 Mataram, SMP Negeri 9 Mataram, SMP Negeri 15 Mataram, dan SMP Negeri 21 Mataram telah disusun dan digunakan oleh guru kelas VII masing-masing sekolah dengan penerapan dua model RPP daring teks prosedur, yakni (1) model pembelajaran berbasis teks yang terintegrasi dengan keterampilan 4C dan literasi serta (2) model pembelajaran berbasis teks yang terintegrasi dengan pendekatan saintifik yang disusun dengan teori yang berlaku dan dengan format yang berbeda-beda (berdasarkan MGMP Kota Mataram, MGMP guru mata pelajaran di sekolah tersebut, dan kelompok guru CPNS mata pelajaran se-Kota Mataram).
\end{abstract}

Kata kunci: RPP Daring, Teks Prosedur, Berbasis Teks

\section{The Drafting of The Implement of learning (RPP) Online Text Procedure by Class Teacher VII} SMP of Mataram During the Covid-19 Pandemic

Abstract: The research aims to know the drafting of the Planned Implementation of Learning (RPP) online text procedure by class teacher VII SMP of Mataram during the covid-19 pandemic. With the type of qualitative research, descriptive qualitative methods, data obtained from objective implementation forms, core activity measures, and RPP assessment of the online text procedure in six schools. Based on the results of research and discussion to answer how the preparation of the online Learning Implementation Plan (RPP) for procedure text by junior high school teachers throughout the city of Mataram during the covid-19 pandemic? Thus, it was found that the online lesson plans for the procedural texts of SMP Negeri 3 Mataram, SMP Negeri 4 Mataram, SMP Negeri 5 Mataram, SMP Negeri 9 Mataram, SMP Negeri 15 Mataram, and SMP Negeri 21 Mataram had been prepared and used by grade VII teachers of each school. with the application of two online lesson plans for procedural texts, namely (l) a text-based learning model that is integrated with $4 \mathrm{C}$ and literacy skills and (2) a text-based learning model that is integrated with a scientific approach, which is compiled with applicable theories, and in a different format (based on the MGMP of Mataram City, the MGMP of subject teachers at the school, and the group of CPNS teachers of subjects throughout the city of Mataram).

Keywords. Online RPP, Procedure Text, Text-Based. 


\section{PENDAHULUAN}

Seperti diketahui bahwa saat ini Indonesia sedang dilanda pandemi covid-19. Dampaknya adalah banyak sektor, termasuk sektor pendidikan, tidak dapat berjalan normal. Pembelajaran secara tatap muka, khususnya di sekolah di Kota Mataram, untuk jenjang SD hingga SMP sementara waktu ditiadakan sehingga pembelajaran jarak jauh (PJJ) menjadi pilihan. Salah satu bentuk pembelajaran jarak jauh (PJJ) ini adalah pembelajaran berbasis daring. Pembelajaran daring tidak sama dengan pembelajaran konvensional yang didaringkan. Artinya, selama pembelajaran daring ini diperlukan perencanaan pembelajaran yang disusun sesuai dengan keadaan. Sejak diterbitkannya Surat Edaran Menteri Pendidikan dan Kebudayaan RI Nomor 4 Tahun 2020 terkait pembelajaran dilakukan secara daring, Pemerintah Kota Mataram sejak bulan Juli lalu juga mengimbau kepada sekolah-sekolah agar pembelajaran dilakukan secara daring. Hal ini tentu berimbas juga pada instrumeninstrumen pembelajaran yang digunakan, salah satunya adalah instrumen rencana pembelajaran.

Sebelumnya, guru Bahasa Indonesia kelas VII SMP di Kota Mataram menyusun rencana pembelajaran dengan format konvensional (dengan tiga belas komponen sesuai dengan Permendikbud Nomor 22 Tahun 2016), namun selama pembelajaran jarak jauh (PJJ) berbasis daring, guru menggunakan format rencana pembelajaran yang sesuai dengan isi Surat Edaran Menteri Pendidikan Nomor 14 Tahun 2019 yang terdiri dari tujuan pembelajaran, langkah-langkah pembelajaran, dan penilaian pembelajaran sebagai komponen inti. Model rencana pembelajaran dengan format itu disebut sebagai Rencana Pelaksanaan Pembelajaran (RPP) daring. Hal ini merupakan salah satu alasan mengapa RPP daring ini patut dikaji lebih dalam karena terdapat fokus penelitian yang baru yakni keberadaan tiga komponen tersebut sebagai komponen inti.

Selain itu, RPP daring adalah salah satu instrumen pembelajaran yang tidak dapat dilepaskan dari peranan guru dalam mengajar selama pembelajaran jarak jauh (PJJ). Oleh karena dua alasan tersebut, penelitian terkait RPP daring (khususnya RPP daring teks prosedur) dianggap penting untuk dilaksanakan. Guru-guru di SMP Negeri 3 Mataram dan SMP Negeri 9 Mataram dalam mengajar saat ini telah menggunakan RPP daring. SMP Negeri 3 Mataram dan SMP Negeri 9 Mataram adalah dua sampel dalam pengumpulan data penelitian ini. Alasan pemilihan sekolah ini sebagai sampel pengumpulan data adalah karena SMP VII merupakan jenjang pendidikan peralihan dari masa anak-anak (SD) menuju remaja awal (SMP kelas VII) sehingga diharapkan lebih mudah dalam pengembangan HOTS para peserta didik. Pemilihan materi teks prosedur mengacu pada pengembangan HOTS siswa kelas VII SMP di kota Mataram yang dapat dilakukan dengan teks prosedur. Berdasarkan latar belakang ini, rumusan masalah penelitian ini adalah bagaimana penyusunan Rencana Pelaksanaan Pembelajaran (RPP) daring teks prosedur oleh guru SMP se-Kota Mataram selama pandemi covid-19? Tujuan penelitian ini adalah untuk mengetahui penyusunan Rencana Pelaksanaan Pembelajaran (RPP) daring tes prosedur oleh guru kelas VII SMP sekota Mataram selama pandemi covid-19. Sebagai jawaban atas rumusan masalah itu, maka akan dibahas sebagai berikut. 


\section{LANDASAN TEORI}

\section{Rencana Pelaksanaan Pembelajaran (RPP)}

Dalam Salinan Permendikbud Nomor 65 Tahun 2013, RPP merupakan rencana yang dikembangkan dari silabus demi terarahnya kegiatan pembelajaran untuk mencapai kompetensi dasar yang diharapkan (Priyatni, 2019). Dalam pengertian ini, kedudukan RPP berada di bawah silabus sehingga RPP merupakan bentuk pengembangan dari silabus. Artinya, RPP dibuat berdasarkan silabus. Berdasarkan Permendikbud Nomor 22 Tahun 2016 tentang Standar Proses Pendidikan Dasar dan Menengah, komponen dalam RPP konvensional terdiri atas tiga belas komponen seperti identitas, kompetensi, indicator, tujuan, dan sebagainya. Berikut akan dipaparkan tentang tujuan pembelajaran, langkahlangkah pembelajaran, dan penilaian menjadi komponen inti pada RPP daring yang sesuai dengan Surat Edaran Menteri Pendidikan Nomor 14 Tahun 2019.

Baik dalam RPP konvensional (yang terdiri dari tiga belas komponen) ataupun dalam RPP daring, tujuan pembelajaran menjadi salah satu komponen yang wajib ada. Hamalik (2014:108) memaparkan tujuan pembelajaran sebagai sejumlah hasil pengajaran kepada peserta didik dan diharapkan akan dicapai oleh mereka, yang mencakup penilaian pada ranah keterampilan dan kecakapan, pengetahuan, serta sikap-sikap yang baru. Tujuan pembelajaran yang baik adalah yang disusun berdasarkan "ABCD", selain mengacu pada KD yang diajarkan dan disesuaikan berdasarkan taksonominya. Seperti halnya yang dinyatakan oleh Sanjaya (2014:86) bahwa terdapat empat komponen pokok (ABCD) yang harus tampak dalam rumusan tujuan pembelajaran yang diuraikan dalam bentuk pertanyaan (1) siapa yang belajar atau yang diharapkan dapat mencapai tujuan pembelajaran atau mencapai hasil belajar? (audience), (2) tingkah laku atau hasil belajar yang bagaimana yang diharapkan dapat dicapai? (behavior), (3) dalam kondisi yang bagaimana hasil belajar itu dapat ditampilkan? (condition), dan (4) seberapa jauh hasil belajar itu bisa diperoleh? (degree) (dalam Rusydi Ananda, 2019:84-87). Keempat komponen itu mengacu pada KD yang diajarkan, selanjutnya, pada bagian behavior atau 'kegiatan pembelajaran yang diharapkan' disesuaikan berdasarkan taksonominya. Sebagai contoh, dengan mengacu pada KD 3.5 (untuk setiap materi teks), tujuan pembelajaran yang disusun dan disesuaikan berdasarkan taksonomi kognitif, karena KD 3.5 merupakan ranah kognitif.

Selanjutnya, penilaian autentik, seperti dinyatakan Nurgiyantoro (2011), merupakan bentuk penilaian yang menekankan pada kemampuan peserta didik untuk mendemonstrasikan pengetahuan yang dimiliki secara nyata dan bermakna (dalam Mahsun, 2014:150). Dengan kata lain, dengan penilaian autentik, peserta didik diminta untuk menunjukkan keterampilan dan kompetensi, pengetahuan, serta sikap yang dimiliki dan dikuasai sebagai penilaian hasil belajar. Terdapat beberapa bentuk penilaian yang dapat dikelompokkan sebagai penilaian autentik, yakni (a) penilaian kinerja, (b) wawancara lisan, (c) pertanyaan terbuka, (d) menceritakan kembali (cerita), (e) portofolio, dan (f) proyek (Nurgiyantoro, 2011 dalam Mahsun, 2014:151). Namun, menurut Mahsun (2014:151), yang dipandang sebagai penilaian autentik yang relevan dengan pembelajaran berbasis teks, yakni (a) pertanyaan terbuka, (b) pendekatan ilmiah dalam pemroduksian teks, (c) proyek, dan (d) portofolio. 


\section{Keterampilan $4 c$}

Selama pembelajaran abad 21, digunakan istilah yang dikenal sebagai 4C yang didefinisikan sebagai empat keterampilan yang telah diidentifikasi sebagai keterampilan abad ke-2l (P2l), yang terdiri dari critical thinking, communication, collaboration, and creativity (Direktorat Jenderal Guru dan Tenaga Kependidikan, 2018). Keempat keterampilan tersebut sangat penting sebagai penunjang keterampilan peserta didik pada masa kini. Perhatikan tabel berikut ini.

Tabel 1

Keterampilan 4C

\begin{tabular}{|l|l|}
\hline \multicolumn{1}{|c|}{ Keterampilan 4C } & \multicolumn{1}{|c|}{ Kompetensi Berpikir } \\
\hline $\begin{array}{l}\text { Creativity Thinking and } \\
\text { innovation }\end{array}$ & $\begin{array}{l}\text { Peserta didik dapat menghasilkan, mengembangkan, dan mengimplementasikan ide-ide } \\
\text { mereka secara kreatif baik secara mandiri maupun berkelompok. }\end{array}$ \\
\hline $\begin{array}{l}\text { Critical Thinking and } \\
\text { Problem Solving }\end{array}$ & $\begin{array}{l}\text { Peserta didik dapat mengidentifikasi, menganalisis, menginterpretasikan, dan } \\
\text { mengevaluasi bukti-bukti, argumentasi, klaim dan data-data yang tersaji secara luas } \\
\text { melalui pengakajian secara mendalam, serta merefleksikannya dalam kehidupan sehari- } \\
\text { hari. }\end{array}$ \\
\hline Communication & $\begin{array}{l}\text { Peserta didik dapat mengomunikasikan ide-ide dan gagasan secara efektif menggunakan } \\
\text { media lisan, tertulis, maupun teknologi. }\end{array}$ \\
\hline Collaboration & $\begin{array}{l}\text { Peserta didik dapat bekerja sama dalam sebuah kelompok dalam memecahkan } \\
\text { permsalahan yang ditemukan. }\end{array}$ \\
\hline
\end{tabular}

Sumber: Direktorat Jenderal Guru dan Tenaga Kependidikan, 2018:14

Keterampilan 4C di atas tidak dapat dilepaskan kaitannya dengan pembelajaran berbasis teks di sekolah. Artinya, selama pembelajaran teks bahasa Indonesia, peserta didik diminta untuk melakukan kegiatan-kegiatan yang telah ditentukan dalam RPP daring teks prosedur yang mengacu pada empat butir keterampilan tersebut. Misalnya, peserta didik diminta untuk mengidentifikasi pengertian, struktur, tujuan, dan jenis suatu teks. Ini termasuk dalam tahapan pertama, yaitu keterampilan critical thinking. Kemudian peserta didik diminta untuk bekerja sama dengan temannya untuk menyelesaikan tugas yang diberikan yang termasuk dalam tahapan kedua yaitu keterampilan collaboration, dst. Tahap pertama menjadi dasar tahap kedua, selanjutnya, tahap pertama dan kedua menjadi dasar tahap ketiga dan seterusnya.

Agar selaras dengan pendekatan saintifik yang terdiri dari kegiatan mengamati, menanya, mengumpulkan informasi, mengasosiasi/mengolah informasi, dan mengomunikasikan, maka RPP daring juga dapat disusun dengan mengacu pada keterampilan 4C yang terintegrasi dengan literasi. Jadi, baik pendekatan saintifik maupun keterampilan 4C yang terintegrasi dengan literasi pada RPP daring sama-sama terdiri dari lima bentuk kegiatan. Kegiatan mengamati dipadankan dengan keterampilan literasi, kegiatan menanya dipadankan dengan keterampilan critical thinking, kegiatan mengumpulkan informasi dipadankan dengan keterampilan collaboration, kegiatan mengasosiasi/mengolah informasi dipadankan dengan keterampilan creative, dan kegiatan mengomunikasikan dipadankan dengan keterampilan communication.

\section{Pembelajaran Berbasis Teks}

Berdasarkan data Programme for International Students Assessment (PISA) yang dirilis oleh the Organisation for Economic Co-operation and Development (OECD) pada tahun 2016, didapati 
bahwa kemampuan peserta didik di Indonesia secara berturut-urut untuk ketiga kemampuan tersebut berada pada peringkat 62, 61, dan 63 (Syaiful, dkk., 2018). Sejalan dengan itu, Mahsun (2014) berpendapat bahwa berdasarkan hasil beberapa studi organisasi dunia terkait kemampuan pemecahan masalah oleh peserta didik didapati bahwa sekitar 95\% peserta didik di Indonesia hanya mampu memecahkan masalah yang bersifat hafalan, dibandingkan dengan jumlah siswa yang mampu memecahkan masalah yang memerlukan pemikiran yang hanya berjumlah sekitar 5\%. Oleh karena itu, fungsi bahasa Indonesia sebagai sarana berpikir manusia (khususnya peserta didik) dalam pembelajaran bahasa Indonesia di sekolah menghadapi persoalan, yakni mengapa pembelajaran bahasa Indonesia yang sudah diajarkan sejak sekolah dasar belum mampu membentuk kemampuan berpikir siswa Indonesia? Sebagai jawaban, Mahsun (2014) menyatakan bahwa kemampuan berpikir yang dimaksud adalah peserta didik mampu berpikir secara sistematis, terkontrol, empiris, dan kritis, yang disebut sebagai kemampuan berpikir metodologis, yang dapat dicapai dengan pendekatan saintifik dalam pembelajaran bahasa Indonesia.

Selain itu, pembelajaran bahasa Indonesia di sekolah (sebelum diaplikasikannya Kurikulum 2013) belum mampu membentuk kemampuan berpikir metodologis peserta didik karena tidak sepenuhnya berbasis pada pembelajaran teks. Jika terdapat teks dalam materi yang diajarkan, hal itu termasuk dalam pembelajaran teks dalam arti sempit sebab baik peserta didik maupun guru masih dibingungkan antara pengertian teks dengan paragraf. Berdasarkan Panduan Pembelajaran untuk Sekolah Menengah Pertama (2016), pembelajaran berbasis teks merupakan salah satu dari enam metode pembelajaran berbasis Kurikulum 2013 yang didefinisikan sebagai pembelajaran yang berorientasi pada kemampuan peserta didik untuk menyusun teks. Dengan metode pembelajaran berbasis teks ini, peserta didik diarahkan agar mampu mengonstruksikan pengetahuannya dan terampil dalam menyusun suatu teks baik lisan maupun tertulis.

Terdapat hal yang perlu diperhatikan dalam menghasilkan suatu teks, yakni diperlukan data, informasi, atau fakta, yang sangat berhubungan dengan jenis teks yang akan dihasilkan. Artinya, tidak semua jenis teks memiliki wujud data, informasi, atau fakta yang sama. Perbedaan wujud data tersebut tidak lain karena perbedaan fungsi atau tujuan sosial dari setiap teks. Hal ini juga berdampak pada perbedaan dalam pengumpulan, analisis, dan penyajian data. Sebagai contoh, pengumpulan, analisis, dan penyajian data pada teks prosedur akan berbeda dengan teks cerita karena fungsi atau tujuan sosial kedua teks itu berbeda. Oleh karena itu, menyusun teks merupakan suatu kegiatan yang kompleks yang membutuhkan aktivitas yang sistematis, terkontrol, empirik, dan kritis atau secara metodologis.

\section{Teks Prosedur}

Teks Prosedur atau arahan merupakan salah satu dari jenis teks yang termasuk genre faktual subgenre prosedural, yang artinya teks ini lebih menekankan aspek bagaimana melakukan sesuatu dengan langkah-langkah yang telah ditentukan sebelumnya (Mahsun, 2014). Sementara itu, menurut Kosasih dan Endang (2018), teks prosedur adalah suatu teks yang menyajikan penjelasan tentang tata cara melakukan sesuatu dengan sejelas-jelasnya. Berdasarkan pengertian dari para ahli di atas, dapat disimpulkan bahwa teks prosedur adalah teks yang termasuk genre faktual subgenre prosedural yang menyajikan paparan penjelasan tentang tata cara melakukan sesuatu dengan sejelas-jelasnya sehingga peserta 
didik diharapkan dapat melakukan suatu pengamatan atau kegiatan yang terarah dan sistematis.

\section{METODOLOGI PENELITIAN}

Jenis penelitian ini adalah kualitatif deskriptif karena data-data dalam penelitian ini berupa kata-kata yang akan dideskripsikan yang dilakukan di Sekolah Menengah Pertama (SMP) sekota Mataram dengan melibatkan enam sekolah yang berbeda sekota Mataram. Masing-masing sekolah ini merupakan perwakilan acak yang dipilih sebagai tempat penelitian untuk mendapatkan data berupa RPP daring teks prosedur, yakni (1) SMPN 9 Mataram di Kecamatan Mataram, (2) SMPN 3 Mataram di Kecamatan Ampenan, (3) SMPN 4 di Kecamatan Cakranegara, (4) SMPN 15 Mataram di Kecamatan Selaparang, (5) SMPN 21 Mataram di Kecamatan Sekarbela, dan (6) SMPN 5 Mataram di Kecamatan Sandubaya. Data dikumpulkan dengan metode dokumentasi dan dianalisis dengan metode interaktif.

Dengan metode interaktif, setiap data yang diperoleh kemudian dikomparasikan dengan data lain secara berkelanjutan dengan memadupadankan tiap-tiap komponen (Farida Nugrahani, 2014). Analisis data menggunakan model Analysis Interactive dari Miles dan Huberman (1994) dengan tahapan-tahapan kegiatan analisis, yaitu: tahapan pengumpulan data/koleksi data, reduksi data, penyajian data, dan penarikan kesimpulan atau verifikasi data (dalam Ilyas, 2016).

Secara sederhana, tahapan-tahapan di atas dapat diuraikan secara singkat sebagai berikut. Data yang dikumpulkan/dikoleksi dengan metode pengumpulan data, kemudian direduksi atau dipilih dan dipilah berdasarkan hal-hal yang menjadi pokok penelitian. Dalam penelitian ini, RPP daring teks prosedur SMP sekota Mataram dikumpulkan/dikoleksi kemudian direduksi bagian yang akan menjadi pokok penelitian, yakni tiga komponen inti yang telah ditetapkan Kemendikbud berdasarkan SE Nomor 14 Tahun 2019 yang meliputi tujuan, langkah-langkah, dan penilaian pembelajaran. Setelah dilakukan reduksi data, tahap selanjutnya adalah penyajian data. Selanjutnya, pada tahap penyajian data, data mentah, yaitu tiga komponen inti RPP daring teks prosedur yang telah direduksi disajikan untuk dianalisis. Penyajian data dalam bentuk deskripsi yang bersifat naratif dan dalam bentuk tabel agar mudah dipahami. Terakhir adalah tahap verifikasi/penarikan simpulan. Setelah data disajikan dalam bentuk deskripsi yang bersifat naratif, hasil analisis data tersebut kemudian disimpulkan, yang kemudian diharapkan dapat menjawab masalah penelitian.

\section{PEMBAHASAN}

\section{Pembahasan Bentuk Implementasi Tujuan Pembelajaran}

Berdasarkan data-data pada tabel 2 di bawah ini terlihat bahwa guru bahasa Indonesia kelas VII SMP Negeri 3 Mataram, SMP Negeri 4 Mataram,SMP Negeri 5 Mataram, SMP Negeri 9 Mataram, SMP Negeri 15 Mataram, dan SMP Negeri 21 Mataram telah menyusun tujuan pembelajaran pada RPP daring teks prosedur yang sesuai dengan rumusan indikator atau KD.

Tabel 2

Bentuk Implementasi pada Komponen Tujuan RPP SMP Negeri 3 Mataram, SMP Negeri 4 Mataram, SMP Negeri 5 Mataram, SMP Negeri 9 Mataram, SMP Negeri 15 Mataram, dan SMP Negeri 21 Mataram

\begin{tabular}{|l|l|l}
\hline Komponen & Keriteria & Bentuk Implementasi
\end{tabular}




\begin{tabular}{|c|c|c|c|}
\hline \multirow[t]{2}{*}{ RPP } & & & \\
\hline & \multirow[b]{2}{*}{ 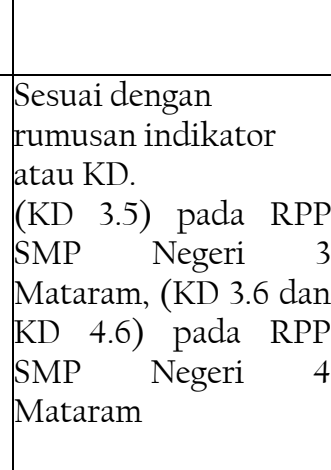 } & RPP Daring SMP Negeri 3 Mataram & RPP Daring SMP Negeri 4 Mataram \\
\hline \multirow[t]{5}{*}{$\begin{array}{l}\text { Tujuan } \\
\text { Pembelajaran }\end{array}$} & & \multicolumn{2}{|c|}{\begin{tabular}{|l} 
Setelah melakukan pembelajaran jarak Mampu menyajikan data rangkaian \\
jauh, peserta didik dapat meng- kegiatan ke dalam bentuk teks \\
identifikasi ciri, tujuan, dan jenis teksprosedur (tentang cara memainkan \\
prosedur. \\
$\begin{array}{l}\text { alat musik daerah, tarian daerah, cara } \\
\text { membuat cendera mata, dan kuliner } \\
\text { khas daerah, dll.) dengan mem- } \\
\text { perhatikan struktur unsur kebahasaan } \\
\text { dan isi secara lisan dan tulis dengan } \\
\text { penuh rasa syukur dan tanggung- } \\
\text { jawab. }\end{array}$
\end{tabular}} \\
\hline & & RPP Daring SMP Negeri 5 Mataram & RPP Daring SMP Negeri 9 Mataram \\
\hline & 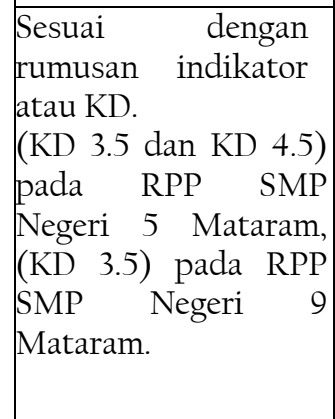 & \multicolumn{2}{|c|}{$\begin{array}{l}\text { Peserta didik mampu meng-identifikasiSetelah melakukan pembelajaran jarak } \\
\text { struktur teks prosedur cara membuatjauh, peserta didik dapat meng- } \\
\text { disinfektan dalam menghadapi Covidlidentifikasi ciri, tujuan, dan jenis teks } \\
\text { 19, peserta didik mampu meng-prosedur. } \\
\text { identifikasi kaidah ke-bahasaan teks } \\
\text { prosedur cara membuat disinfektan } \\
\text { dalam menghadapi Covid 19, dan } \\
\text { peserta didik mampu membuat teks } \\
\text { prosedur tentang cara membuat } \\
\text { disinfektan dalam menghadapi Covid 19. }\end{array}$} \\
\hline & & RPP Daring SMP Negeri 15 Mataram & RPP Daring SMP Negeri 21 Mataram \\
\hline & \multicolumn{3}{|c|}{\begin{tabular}{lr|l} 
Sesuai & dengan & Memahami struktur teks dalam bagian Memahami tentang pengertian, ciri, \\
rumusan & indikator & tujuan teks prosedur; menentukan ciridan tujuan teks prosedur. \\
atau KD. & & umum teks prosedur pada teks yang \\
(KD 3.6) pada & RPP & dibaca/didengar; dan mendaftar \\
SMP Negeri 15 & kata/kalimat sebagai ciri teks prosedur \\
Mataram dan SMP & pada teks yang dibaca/didengar. \\
Negeri 2l Mataram.
\end{tabular}} \\
\hline
\end{tabular}

Berdasarkan pada tabel 2 di atas terlihat bahwa bentuk implementasi tujuan pembelajaran di keenam sekolah tersebut disusun dan dikembangkan dari KD yang berbeda, yaitu KD 3.5 saja seperti pada RPP daring teks prosedur SMP Negeri 3 Mataram, SMP Negeri 5 Mataram, dan SMP Negeri 9 Mataram. Sementara itu, KD 3.6 dan KD 4.6 pada RPP daring teks prosedur SMP Negeri 4 Mataram, SMP Negeri 15 Mataram, dan SMP Negeri 21 Mataram. Permasalahan kesamaan KD 3.5 pada RPP daring teks prosedur SMP Negeri 3 Mataram, SMP Negeri 9 Mataram, dan SMP Negeri 5 Mataram dapat terjadi karena KD yang tertera pada RPP daring teks prosedur di ketiga sekolah tersebut sama. Begitu juga halnya dengan kesamaan KD 3.6 dan KD 4.6 pada RPP daring teks prosedur SMP Negeri 4 Mataram, SMP Negeri 15 Mataram, dan SMP Negeri 21 Mataram. Alasan mengapa KD yang digunakan pada RPP daring teks prosedur di keenam sekolah tersebut berbeda karena submateri yang diajarkan dalam pertemuan yang berbeda. Tentu saja hal ini tidak dapat dikritisi lebih jauh, mengingat guru mata pelajaran, khususnya guru bahasa Indonesia kelas VII dapat menyusun dan menyesuaiakan RPP daring teks prosedur berdasarkan kebutuhan dan keadaan peserta didik. 
Akan tetapi, yang menjadi persoalan adalah apakah bentuk implementasi tujuan pada RPP daring teks prosedur di keenam sekolah tersebut di atas telah disusun dengan baik dan benar? Secara sekilas, terlihat bahwa bentuk implementasi tujuan pada RPP daring teks prosedur di keenam sekolah tersebut (pada tabel 2 di atas) telah disusun dan dikembangkan berdasarkan masing-masing KD yang digunakan. Namun, apabila dilihat dengan seksama berdasarkan teori perumusan tujuan pembelajaran, bentuk implementasi tujuan pada RPP daring teks prosedur SMP Negeri 3 Mataram dan SMP Negeri 9 Mataram hanya disusun berdasarkan (a) audience (peserta didik), (b) behavior (...mengidentifikasi ciri, tujuan, dan jenis teks prosedur), dan (c) condition (pembelajaran jarak jauh....), sedangkan pada RPP daring teks prosedur SMP Negeri 21 Mataram hanya disusun berdasarkan behavior (memahami tentang pengertian, ciri, dan tujuan teks prosedur). Sementara itu, bentuk implementasi tujuan para RPP daring teks prosedur SMP Negeri 4 Mataram tersusun dari (a) behavior (...menyajikan data rangkaian kegiatan ke dalam bentuk teks prosedur... dengan memperhatikan struktur unsur kebahasaan dan isi secara lisan dan tulis...) dan (b) degree (...dengan penuh rasa syukur dan tanggungjawab.), sedangkan pada RPP daring teks prosedur SMP Negeri 15 Mataram tersusun dari (a) behavior (memahami struktur, menentukan ciri umum, dan mendaftar kata/kalimat sebagai ciri teks prosedur pada teks yang dibaca/ didengar.). Berbeda dengan kedua bentuk implementasi tersebut, bentuk implementasi tujuan pada RPP daring teks prosedur SMP Negeri 5 Mataram tersusun dari (a) audience (peserta didik) dan (b) behavior (mengidentifikasi struktur, kaidah kebahasaan, dan membuat teks prosedur cara membuat disinfektan dalam menghadapi Covid 19).

Berdasarkan penjabaran di atas, terlihat bahwa bentuk implementasi tujuan pada RPP daring teks prosedur di keenam sekolah tersebut hanya disusun dengan baik, yang didasarkan atas keadaan dan kebutuhan peserta didik, namun tidak disusun dengan benar karena tidak tersusun atas empat syarat perumusan tujuan pembelajaran tersebut. Namun, terlepas dari aturan itu, bentuk-bentuk implemenntasi tujuan pembelajaran tersebut disusun dan dikembangkan dari masing-masing KD ranah kognitif dan psikomotorik.

\section{Pembahasan Langkah-Langkah Bagian Kegiatan Inti}

Berdasarkan data-data pada tabel 3-7 di bawah ini terlihat bahwa guru bahasa Indonesia kelas VII SMP Negeri 3 Mataram, SMP Negeri 4 Mataram,SMP Negeri 5 Mataram, SMP Negeri 9 Mataram, SMP Negeri 15 Mataram, dan SMP Negeri 21 Mataram telah menyusun langkah-langkah bagian kegiatan inti pembelajaran teks prosedur dengan cermat.

\section{Tabel 3}

Bentuk Implementasi Langkah-Langkah Bagian Kegiatan Inti (Subkegiatan Literasi) RPP Daring Teks Prosedur SMP Negeri 3 Mataram, SMP Negeri 4 Mataram, SMP Negeri 5 Mataram, SMP Negeri 9 Mataram, SMP Negeri 15 Mataram, dan SMP Negeri 21 Mataram

\begin{tabular}{|l|l|l|}
\hline \multicolumn{3}{|c|}{ Bentuk Implementasi Langkah-Langkah Bagian Kegiatan Inti } \\
(Subkegiatan Literasi)
\end{tabular}




\begin{tabular}{|c|c|c|}
\hline RPP SMP Negeri 9 Mataram & RPP SMP Negeri 15 Mataram & RPP SMP Negeri 21 Mataram \\
\hline $\begin{array}{l}\text { eserta didik diminta untu } \\
\text { lencermati teks atau vide } \\
\text { ersebut. }\end{array}$ & $\begin{array}{l}\text { Peserta didik diberi motivasi d } \\
\text { panduan untuk melihat, mengama } \\
\text { membaca dan menuliskannya ke } \\
\text { bali. Mereka diberi tayangan d } \\
\text { bahan bacaan terkait materi strukt } \\
\text { teks prosedur dalam bagian tuju } \\
\text { dengan mengunjungi laman } \\
\text { https:gurubindmaju.blogspot.com. }\end{array}$ & $\begin{array}{l}\text { Peserta didik diberi motivasi dar } \\
\text { panduan untuk melihat, mengamat } \\
\text { membaca dan menuliskannya kembal } \\
\text { Peserta didik diberi tayangan dar } \\
\text { bahan bacaan terkait materi struktu } \\
\text { teks prosedur dalam bagian alat dar } \\
\text { langkah dengan mengunjungi laman } \\
\text { https:gurubindmaju.blogspot.com. }\end{array}$ \\
\hline
\end{tabular}

Seperti yang telah dijabarkan pada bab terdahulu bahwa literasi merupakan salah satu dari lima keterampilan yang diajarkan pada abad ke-2l ini, yakni sebuah kegiatan yang terkait dengan kegiatan membaca, menulis, dan kompetensi kebahasaan peserta didik. Bentuk implementasi kegiatan pertama pada langkah-langkah bagian kegiatan inti pada RPP daring teks prosedur SMP Negeri 3 Mataram, SMP Negeri 4 Mataram, SMP Negeri 5 Mataram, SMP Negeri 9 Mataram, SMP Negeri 15 Mataram, dan SMP Negeri 21 Mataram telah disusun dan disesuaikan berdasarkan pembelajaran daring, yaitu pembelajaraan menggunakan media daring, misalnya YouTube dan tautan dari peramban tentang materi terkait teks prosedur. Artinya, pembelajaran teks prosedur kepada peserta didik di keenam sekolah tersebut diajarkan melalui media daring. Oleh karena itu, hal ini dapat dimasukkan sebagai bentuk implementasi kegiatan literasi.

Tabel 4

Bentuk Implementasi Langkah-Langkah Bagian Kegiatan Inti (Subkegiatan Berpikir Kritis) RPP SMP Negeri 3 Mataram, SMP Negeri 4 Mataram, SMP Negeri 5 Mataram, SMP Negeri 9 Mataram, SMP Negeri 15 Mataram, dan SMP Negeri 21 Mataram

\begin{tabular}{|c|c|c|}
\hline \multicolumn{3}{|c|}{$\begin{array}{c}\text { Bentuk Implementasi Langkah-Langkah Bagian Kegiatan Inti } \\
\text { (Subkegiatan Berpikir Kritis) }\end{array}$} \\
\hline RPP SMP Negeri 3 Mataram & RPP SMP Negeri 4 Mataram & RPP SMP Negeri 5 Mataram \\
\hline $\begin{array}{l}\text { Berdasarkan penjelasan dalam } \\
\text { video tersebut, siswa menye- } \\
\text { butkan dan menjelaskan penger- } \\
\text { tian, ciri, dan tujuan teks } \\
\text { prosedur. }\end{array}$ & $\begin{array}{l}\text { Peserta didik menyampaikan } \\
\text { pertanyaan-pertanyaan terkait dari } \\
\text { tayangan video. }\end{array}$ & $\begin{array}{l}\text { Peserta didik menyampaikan } \\
\text { pertanyaan-pertanyaan terkait dari } \\
\text { tayangan video. }\end{array}$ \\
\hline RPP SMP Negeri 9 Mataram & RPP SMP Negeri 15 Mataram & RPP SMP Negeri 21 Mataram \\
\hline $\begin{array}{l}\text { Guru dan peserta didik bertanya } \\
\text { jawab tentang ciri, tujuan, dan } \\
\text { jenis teks prosedur tersebut. }\end{array}$ & $\begin{array}{l}\text { Guru memberikan kesempatan } \\
\text { untuk mengidentifikasi sebanyak } \\
\text { mungkin hal yang belum dipahami, } \\
\text { dimulai dari pertanyaan faktual } \\
\text { sampai ke pertanyaan yang bersifat } \\
\text { hipotetik. Pertanyaan ini harus } \\
\text { tetap berkaitan dengan materi } \\
\text { struktur teks prosedur dalam } \\
\text { bagian tujuan. }\end{array}$ & $\begin{array}{l}\text { Guru memberikan kesempatan } \\
\text { untuk mengidentifikasi sebanyak } \\
\text { mungkin hal yang belum dipahami, } \\
\text { dimulai dari pertanyaan faktual } \\
\text { sampai ke pertanyaan yang bersifat } \\
\text { hipotetik. Pertanyaan ini harus } \\
\text { tetap berkaitan dengan materi } \\
\text { struktur teks prosedur dalam } \\
\text { bagian alat dan langkah. }\end{array}$ \\
\hline
\end{tabular}

Berdasarkan tabel di atas, bentuk implementasi dari berpikir kritis pada RPP daring teks prosedur SMP Negeri 15 Mataram dan SMP Negeri 21 Mataram adalah mengidentifikasi sebanyak mungkin hal yang belum dipahami, dimulai dari pertanyaan faktual sampai ke pertanyaan yang bersifat hipotetik. Artinya, setelah peserta didik melakukan literasi dengan saranan daring, mereka diminta untuk menentukan hal-hal terkait teks prosedur yang belum 
dipahami, selanjutnya, mempertanyakan hal-hal tersebut. Sementara itu, pada SMP Negeri 3 Mataram, SMP Negeri 4 Mataram, SMP Negeri 5 Mataram, dan SMP Negeri 9 Mataram tidak digunakan salah satu dari keempat kategori berpikir kritis di atas. Sebagai gantinya, peserta didik diberikan ruang dan waktu untuk bertanya, menyebutkan, dan menjelaskan teks prosedur. Namun, hal ini masih dapat dikatakan sebagai bentuk implementasi berpikir kritis karena dilakukan setelah peserta didik mengamati video atau membaca pembahasan materi (literasi) dan menanyakan atau menjelaskan materi yang dibaca.

Tabel 5

Bentuk Implementasi Langkah-Langkah Bagian Kegiatan Inti (Subkegiatan Kerja Sama) RPP SMP Negeri 3 Mataram, SMP Negeri 4 Mataram, SMP Negeri 5 Mataram, SMP Negeri 9 Mataram, SMP Negeri 15 Mataram, dan SMP Negeri 21 Mataram

\begin{tabular}{|c|c|c|}
\hline \multicolumn{3}{|c|}{$\begin{array}{l}\text { Bentuk Implementasi Langkah-Langkah Bagian Kegiatan Inti } \\
\text { (Subkegiatan Kerja Sama) }\end{array}$} \\
\hline RPP SMP Negeri 3 Mataram & RPP SMP Negeri 4 Mataram & RPP SMP Negeri 5 Mataram \\
\hline $\begin{array}{l}\text { Siswa menyimpulkan pengertian, } \\
\text { ciri-ciri objek, tujuan, dan isi teksprta didik membuat teks Peserta didik berdiskusi dalam forum } \\
\text { prosedur di buku catatan masing- } \\
\text { masing. }\end{array}$ & $\begin{array}{l}\text { Pesedur. } \\
\text { di google classroom dalam membuat teks } \\
\text { prosedur cara membuat disinfektan } \\
\text { dalam menghadapi covid 19. }\end{array}$ \\
\hline RPP SMP Negeri 9 Mataram & RPP SMP Negeri 15 Mataram & RPP SMP Negeri 21 Mataram \\
\hline Peserta didik mengerjakan LKPD. & $\begin{array}{l}\text { Peserta didik dibentuk dalamPeserta didik dibentuk dalam } \\
\text { beberapa kelompok untuk beberapa kelompok untuk men- } \\
\text { mendiskusikan, mengumpulkan in- diskusikan, mengumpulkan informasi, } \\
\text { formasi, mem-presentasikan ulang,mempresentasikan ulang, dan saling } \\
\text { dan saling bertukar informasibertukar informasi mengenai struktur } \\
\text { mengenai struktur teks prosedur teks prosedur dalam bagian alat dan } \\
\text { dalam bagian tujuan. }\end{array}$ \\
\hline
\end{tabular}

Berdasarkan tabel di atas, bentuk implementasi subkegiatan kerja sama pada RPP daring teks prosedur SMP Negeri 15 Mataram dan SMP Negeri 21 Mataram di atas adalah peserta didik mendiskusikan, mengumpulkan informasi, mempresentasikan ulang, dan saling bertukar informasi mengenai struktur teks prosedur atau pada RPP daring teks prosedur SMP Negeri 9 Mataram, yakni peserta didik diminta untuk mengerjakan LKPD. Sementara itu, dalam subkegiatan kerja sama pada RPP daring teks prosedur SMP Negeri 5 Mataram, peserta didik diharapkan dapat menyikapi kondisi pandemi ini sehingga hasil karya ini dapat dijadikan sebagai salah satu alat pencegahan penyebaran covid-19 dengan menyelesaikan tugas teks prosedur cara membuat desinfektan. Perbedaan kegiatan atau proyek yang harus diselesaikan peserta didik tidaklah menjadi masalah yang signifikan karena hal ini dapat disesuaikan dengan keadaan dan kebutuhan sekolah dan peserta didik. Dalam kegiatan kerja sama, peserta didik diminta untuk menyelesaikan suatu proyek yang telah ditentukan baik secara individu maupun berkelompok. Oleh karena itu, bentuk implementasi di keenam RPP daring teks prosedur di atas dapat dikelompokkan ke dalam kegiatan kerja sama.

Tabel 6

Bentuk Implementasi Langkah-Langkah Bagian Kegiatan Inti (Subkegiatan Komunikasi) RPP SMP Negeri 3 Mataram, SMP Negeri 4 Mataram, SMP Negeri 5 Mataram, SMP Negeri 9 Mataram, SMP Negeri 15 Mataram, dan SMP Negeri 21 Mataram 


\begin{tabular}{|c|c|c|}
\hline \multicolumn{3}{|c|}{$\begin{array}{c}\text { Bentuk Implementasi Langkah-Langkah Bagian Kegiatan Inti } \\
\text { (Subkegiatan Komunikasi) }\end{array}$} \\
\hline RPP SMP Negeri 3 Mataram & RPP SMP Negeri 4 Mataram & RPP SMP Negeri 5 Mataram \\
\hline $\begin{array}{l}\text { Siswa mengirim foto has } \\
\text { pembelajaran hari ini melalu } \\
\text { Google Classroom. }\end{array}$ & $\begin{array}{l}\text { Peserta didik secara berkelompok } \\
\text { imenyajikan teks prosedur yang telah } \\
\text { dibuat melalui pesan suara ataupun } \\
\text { video dalam WAG dan ditanggapi oleh } \\
\text { kelompok lain dalam WAG. }\end{array}$ & $\begin{array}{l}\text { Peserta didik mewakili kelompoknya } \\
\text { memaparkan hasil diskusi kelompok } \\
\text { terkait struktur dan kaidah kebahasaan } \\
\text { teks prosedur (tujuan, bahan dan alat, } \\
\text { langkah-langkah membuat disinfektan } \\
\text { dalam menghadapi covid-19), kelompok } \\
\text { yang lain menanggapi. }\end{array}$ \\
\hline RPP SMP Negeri 9 Mataram & RPP SMP Negeri 15 Mataram & RPP SMP Negeri 21 Mataram \\
\hline ter & $\begin{array}{l}\text { Peserta didik mempresentasikan hasi } \\
\text { kerja kelompok atau individu secara } \\
\text { klasikal, mengemukakan pendapat atas } \\
\text { presentasi yang dilakukan kemudian } \\
\text { ditanggapi kembali oleh kelompok atau } \\
\text { individu yang mempresentasikan. }\end{array}$ & $\begin{array}{l}\text { Peserta didik mempresentasikan hasil } \\
\text { kerja kelompok atau individu secara } \\
\text { klasikal, mengemukakan pendapat atas } \\
\text { presentasi yang dilakukan kemudian } \\
\text { ditanggapi kembali oleh kelompok atau } \\
\text { individu yang mempresentasikan. }\end{array}$ \\
\hline
\end{tabular}

Berdasarkan tabel di atas, bentuk implementasi subkegiatan komunikasi yang dimaksud adalah kemampuan peserta didik dalam mengungkapkan ide, gagasan, ataupun pendapat terkait teks prosedur selama pembelajaran daring. Misalnya, guru bahasa Indonesia kelas VII SMP Negeri 3 Mataram dan SMP Negeri 4 Mataram menyusun bentuk implementasi subkegiatan komunikasi, yaitu menginstruksikan peserta didik agar mengirim tugas atau hasil pembelajaran teks prosedur melalui WhatApps dan Google Classroom. Sementara itu, guru bahasa Indonesia kelas VII SMP Negeri 5 Mataram, SMP Negeri 15 Mataram, dan SMP Negeri 21 Mataram menyusun instruksi agar peserta didik baik secara kelompok maupun individu mempresentasikan hasil pembelajaran dan penugasan yang diberikan, namun secara tertulis pada tabel 5.5 di atas hasil ini tidak jelas apakah disampaikan melalui WhatApps, Google Classroom, atau media sosial lainnya. Berbeda dengan kelima sekolah tersebut, guru bahasa Indonesia kelas VII SMP Negeri 9 Mataram tidak menyusun bentuk implementasi komunikasi.

Tabel 7

Bentuk Implementasi Langkah-Langkah Bagian Kegiatan Inti (Subbagian Kreatif) RPP SMP Negeri 3 Mataram, SMP Negeri 4 Mataram, SMP Negeri 5 Mataram, SMP Negeri 9 Mataram, SMP Negeri 15 Mataram, dan SMP Negeri 21 Mataram

Bentuk Implementasi Langkah-Langkah Bagian Kegiatan Inti

(Subbagian Kreatif)

\begin{tabular}{l|l|l} 
RPP SMP Negeri 3 Mataram & RPP SMP Negeri 4 Mataram & RPP SMP Negeri 5 Mataram
\end{tabular}

Guru dan siswa merefleksikanGuru dan peserta merefleksikan

pembelajaran melalui komentar dihasil pembelajaran yang telah

tugas kelas ataupun WA. berlangsung.

\begin{tabular}{l|l|l}
\hline RPP SMP Negeri 9 Mataram & RPP SMP Negeri 15 Mataram & RPP SMP Negeri 21 Mataram
\end{tabular}

Guru dan peserta didikGuru dan peserta didik membuatGuru dan peserta didik membuat menyimpulkan ciri, tujuan, dankesimpulan tentang hal-hal yangkesimpulan tentang hal-hal yang telah jenis teks prosedur. $\quad$ telah dipelajari terkait struktur teksdipelajari terkait struktur teks prosedur prosedur dalam bagian tujuan. dalam bagian alat dan langkah.

Berdasarkan tabel 1 terdahulu, bagian bentuk kompetensi berpikir subkegiatan kreatif, yakni peserta didik dapat mengklasifikasikan, mengembangkan, dan 
mengimplementasikan ide atau gagasan mereka terkait teks prosedur. Bentuk implementasi subkegiatan kreatif yang disusun guru bahasa Indonesia pada tabel 7 di atas dapat dikelompokkan sebagai bentuk implementasi kreatif sebab guru dan/atau peserta didik merefleksikan dan menyimpulkan pembelajaran teks prosedur sehingga peserta didik dapat lebih memahami tentang teks prosedur dan kegiatan yang ditugasi. Namun, terlihat tidak semua RPP daring teks prosedur di keenam sekolah tersebut mengandung bentuk implementasi subkegiatan kreatif pada tabel 7 di atas. RPP daring teks prosedur SMP Negeri 5 Mataram merupakan satu-satunya RPP daring yang tidak terdapat bentuk implementasi subkegiatan kreatif di dalamnya. Padahal, jika dilihat secara saksama, kegiatan pembuatan desinfektan pada RPP daring teks prosedur tersebut merupakan kegiatan yang lebih sesuai keadaan dan kebutuhan peserta didik saat pandemi ini dibandingkan dengan lima RPP daring lainnya.

Kendati bentuk implementasi langkah-langkah bagian kegiatan inti pada RPP daring teks prosedur di keenam sekolah tersebut telah disusun dan disesuaikan berdasarkan pembelajaran daring saat ini, namun model pembelajaran yang digunakan tidaklah sama sehingga akan berdampak pada bentuk kegiatan yang digunakan. RPP daring teks prosedur SMP Negeri 3 Mataram, SMP Negeri 5 Mataram, SMP Negeri 9 Mataram, SMP Negeri 15 Mataram, dan SMP Negeri 21 Mataram menggunakan model pembelajaran berbasis teks yang terintegrasi dengan keterampilan $4 \mathrm{C}$ dan literasi yang ditandai dengan bentuk kegiatan berpikir kritis, berkolaborasi, berkomunikasi, kreatif, dan literasi. Sementara itu, RPP daring teks prosedur SMP 4 Mataram menggunakan model pembelajaran berbasis teks yang terintegrasi dengan pendekatan saintifik yang ditandai dengan bentuk kegiatan mengamati, menanya, mengeksplorasi, mengasosiasi, dan mengomunikasikan.

RPP daring teks prosedur SMP Negeri 4 Mataram tidak mencantumkan bentuk kegiatan kreatif. Namun, terlepas dari perbedaan-perbedaan itu, model pembelajaran berbasis teks yang terintegrasi dengan keterampilan $4 \mathrm{C}$ dan literasi serta pembelajaran berbasis teks yang terintegrasi dengan pendekatan saintifik memiliki tujuan yang sama, yakni mengembangkan potensi berpikir peserta didik dengan pembelajaran bahasa Indonesia, materi teks prosedur.

Sebagai catatan, pada masa pembelajaran abad ke-2l ini yang dibarengi dengan pembelajaran jarak-jauh (PJJ), semestinya guru bahasa Indonesia kelas VII SMP Negeri 3 Mataram, SMP Negeri 4 Mataram, SMP Negeri 5 Mataram, SMP Negeri 9 Mataram, SMP Negeri 15 Mataram, dan SMP Negeri 21 Mataram tidak sekadar menyusun RPP daring teks prosedur, khususnya bagian langkah-langkah pada kegiatan inti. Bentuk kegiatan dan bentuk implementasi langkah-langkah pada kegiatan inti dapat disusun dengan mengolaborasikan keterampilan 4C dengan pendekatan saintifik sehingga pembelajaran menjadi efisien, efektif, dan mampu meningkatkan berpikir metodologis peserta didik. Sebagai contoh, peserta didik diarahkan dan diinstruksikan dengan jelas terkait pembuatan cairan desinfektan, dengan menggunakan pendekatan saintifik atau berbasis proyek.

\section{Pembahasan Bentuk Implementasi Penilaian Pembelajaran}

Berdasarkan data-data pada tabel 8-10 di bawah terlihat bahwa guru Bahasa Indonesia kelas VII SMP Negeri 3 Mataram, SMP Negeri 4 Mataram,SMP Negeri 5 Mataram, SMP Negeri 9 Mataram, SMP Negeri 15 Mataram, dan SMP Negeri 21 Mataram telah menyusun penilaian pembelajaran pada RPP daring teks prosedur. 
Tabel 8

Bentuk Implementasi Penilaian Pembelajaran RPP Daring Teks Prosedur SMP Negeri 5 Mataram

\begin{tabular}{|l|l|}
\hline \multicolumn{1}{|c|}{ Kriteria } & \multicolumn{1}{|c|}{ Bentuk Implementasi } \\
\hline a. Sikap (jurnal, kehadiran, dan kedisiplinan). & - \\
\hline b. Pengetahuan ( tes tulis atau lisan). & - \\
\hline $\begin{array}{l}\text { c. Keterampilan (tes tulis, lisan, atau } \\
\text { keduanya). }\end{array}$ & $\begin{array}{l}\text { Teknik penilaian : penilaian berbasis portofolio } \\
\text { dan proyek. }\end{array}$ \\
\hline
\end{tabular}

Jika merujuk pada definisi penilaian pembelajaran pada bab terdahulu, bentuk implementasi penilaian pada RPP daring teks prosedur SMP Negeri 5 Mataram pada tabel 8 di atas tentunya masih kurang terutama pada bagian penilaian ranah pengetahuan dan sikap. Sebaliknya, bentuk implementasi penilaian pembelajaran pada RPP daring teks prosedur di atas termasuk dalam salah satu dari jenis penilaian autentik, yaitu berbentuk penilaian berbasis portofolio dan proyek. Namun, bentuk implementasi penilaian pembelajaran itu seyogyanya tidak hanya terdiri dari penilaian keterampilan saja karena mengingat KD yang digunakan adalah KD ranah kognitif (pengetahuan) dan KD ranah psikomotorik (keterampilan). Dengan kata lain, guru bahasa Indonesia kelas VII SMP Negeri 5 Mataram dalam menyusun RPP daring teks prosedur itu menampilkan secara tersurat penilaian kedua ranah kompetensi peserta didik tersebut.

Tabel 9

Bentuk Implementasi Penilaian Pembelajaran RPP Daring Teks Prosedur SMP Negeri 9 Mataram

\begin{tabular}{|l|l|}
\hline \multicolumn{1}{|c|}{ Kriteria } & \multicolumn{1}{|c|}{ Bentuk Implementasi } \\
\hline a. Sikap (jurnal, kehadiran, dan kedisiplinan). & $\begin{array}{l}\text { Kedisiplinan mengumpulkan tugas tepat waktu dan } \\
\text { kesopanan ketika berkomunikasi secara online lewat } \\
\text { WAG. }\end{array}$ \\
\hline b. Pengetahuan ( tes tulis atau lisan). & $\begin{array}{l}\text { Siswa mengerjakan tugas/LKPD kemudian hasil } \\
\text { pekerjaanya dikirim melalui WA. }\end{array}$ \\
\hline $\begin{array}{l}\text { c. Keterampilan (tes tulis, lisan, atau } \\
\text { keduanya). }\end{array}$ & \multicolumn{1}{|c|}{-} \\
\hline
\end{tabular}

Berbanding terbalik dengan SMP Negeri 5 Mataram, bentuk implementasi penilaian pembelajaran pada RPP daring teks prosedur SMP Negeri 9 Mataram seperti pada tabel 5.8 di atas hanya terdiri dari dua penilaian peserta didik yaitu penilaian pengetahuan dan sikap. Guru bahasa Indonesia kelas VII SMP Negeri 9 Mataram tidak menyusun bentuk implementasi penilaian keterampilan karena KD yang digunakan hanya KD 3.5 (ranah pengetahuan).

Tabel 10

Bentuk Implementasi Penilaian Pembelajaran RPP Daring Teks Prosedur SMP Negeri 9 Mataram

\begin{tabular}{|l|l|l|l|}
\hline \multicolumn{1}{|c|}{ Kriteria } & \multicolumn{3}{|c|}{ Bentuk Implementasi Penilaian pada RPP Daring Teks Prosedur } \\
\cline { 2 - 4 } & SMP Negeri 4 Mataram & SMP Negeri 15 Mataram & SMP Negeri 21 Mataram \\
\hline $\begin{array}{l}\text { Sikap (jurnal, keha } \\
\text { diran, dan kedisiplin } \\
\text { an). }\end{array}$ & & \\
\hline $\begin{array}{l}\text { Pengetahuan (tes tulis } \\
\text { atau lisan). }\end{array}$ & $\begin{array}{l}\text { Tes tertulisi (jurnal). } \\
\text { tertulis uraian, tes lisan }\end{array}$ & \\
\hline
\end{tabular}




\begin{tabular}{|l|l|l|}
\hline & & $\begin{array}{l}\text { observasi terhadap diskusiobservasi terhadap diskusi } \\
\text { tanya jawab dan percakapantanya jawab dan percakapan } \\
\text { serta penugasan. }\end{array}$ \\
\hline $\begin{array}{l}\text { Keterampilan } \\
\text { tulis, lisan, atau penugasan. } \\
\text { duanya) }\end{array}$ & $\begin{array}{l}\text { (tes } \begin{array}{l}\text { Penilaian unjuk kerja } \\
\text { penilaian proyek, penilaian } \\
\text { produk dan penilaian unjuk kerja, penilaian Penilaian unjuk kerja } \\
\text { portofolio. }\end{array} \\
\text { penilaian penilaian portofolio. }\end{array}$ & $\begin{array}{l}\text { Penian produk dan penilaian proyek, penilaian } \\
\text { produk dan penilaian por- } \\
\text { tofolio. }\end{array}$ \\
\hline
\end{tabular}

Sementara itu, pada tabel 10 di atas terlihat bahwa bentuk implementasi penilaian ranah keterampilan pada RPP daring teks prosedur SMP Negeri 4 Mataram, SMP Negeri 15 Mataram, dan SMP Negeri 21 Mataram adalah sama, yaitu penilaian yang berbentuk unjuk kerja, penilaian proyek, penilaian produk, dan penilaian portofolio. Hal ini telah sesuai dengan jenis-jenis penilaian pembelajaran yang telah dibahas pada bab sebelumnya. Namun, ketiga ranah penilaian peserta didik (sikap, pengetahuan, dan keterampilan) hanya terdapat pada RPP daring teks prosedur SMP Negeri 4 Mataram, sedangkan pada RPP daring teks prosedur SMP Negeri 15 Mataram dan SMP Negeri 21 Mataram sama-sama terdapat dua penilaian beserta bentuk implementasinya yaitu ranah pengetahuan dan keterampilan. Bentuk implementasi penilaian peserta didik di ketiga RPP daring teks prosedur ini telah sesuai dengan KD yang digunakan, yaitu KD. 3.6 (ranah pengetahuan) dan KD 4.6 (ranah keterampilan).

Persoalan apakah bentuk-bentuk implementasi penilaian pembelajaran pada RPP daring teks prosedur di keenam sekolah tersebut disusun dengan benar, tentunya dapat dijawab sebagai berikut. Perihal benar dan salah dari bentuk-bentuk implementasi penilaian pembelajaran itu adalah sebuah kerelatifan karena dalam penyusunannya berdasarkan atas keadaan dan kebutuhan peserta didik yang berbeda-beda antara satu sekolah dengan sekolah lainnya. Selain itu, bentuk penilaian pembelajaran juga didasarkan pada KD yang akan diajarkan kepada peserta didik. Oleh karena itu, bentuk-bentuk implementasi penilaian pembelajaran itu telah disusun sesuai dengan teori yang berlaku serta didasarkan atas keadaan dan kebutuhan peserta didik.

\section{PENUTUP}

Berdasarkan hasil penelitian dan pembahasan untuk menjawab bagaimana penyusunan Rencana Pelaksanaan Pembelajaran (RPP) daring teks prosedur oleh guru SMP sekota Mataram selama pandemi covid-19?, ditemukan RPP daring teks prosedur SMP Negeri 3 Mataram, SMP Negeri 4 Mataram, SMP Negeri 5 Mataram, SMP Negeri 9 Mataram, SMP Negeri 15 Mataram, dan SMP Negeri 21 Mataram telah disusun dan digunakan oleh guru kelas VII masing-masing sekolah dengan penerapan dua model RPP daring teks prosedur, yakni (1) model pembelajaran berbasis teks yang terintegrasi dengan keterampilan 4C dan literasi serta (2) model pembelajaran berbasis teks yang terintegrasi dengan pendekatan saintifik, yang disusun dengan teori yang berlaku, dan dengan format yang berbeda-beda (berdasarkan MGMP Kota Mataram, MGMP guru mata pelajaran di sekolah tersebut, dan kelompok guru CPNS mata pelajaran se-Kota Mataram).

\section{DAFTAR PUSTAKA}

Ananda, Rusydi. 2019. Perencanaan Pembelajaran. Medan: LPPPI. 
Hamalik, Oemar. 2014. Perencanaan Pengajaran Berdasarkan Pendekatan Sistem. Jakarta: PT Bumi Aksara.

Ilyas. 2016. Pendidikan Karakter Melalui Homeschooling: 94.

Kementerian Pendidikan dan Kebudayaan. 2016. Panduan Pembelajaran untuk Sekolah Menengah Pertama. Jakarta: Direktorat Jenderal Pembinaan Sekolah Menengah Pertama. . 2018. Buku Pegangan Pembelajaran Berorientasi pada Keterampilan Berpikir Tingkat Tinggi Program Peningkatan Kompetensi Pembelajaran Berbasis Zonasi. Jakarta: Direktorat Jenderal Guru dan Tenaga Kependidikan.

Kosasih, E., dan Endang Kurniawan. 2018. Jenis-Jenis Teks Fungsi, Struktur, dan Kaidah Kebahasaan Mata Pelajaran Bahasa Indonesia SMP/MTs. Bandung: PENERBIT YRAMA WIDYA.

Mahsun. 2014. Teks dalam Pembelajaran Bahasa Indonesia Kurikulum 2013. Depok: PT RajaGrafindo Persada.

2017. Metode Penelitian Bahasa Tahapan, Strategi, Metode, dan Tekniknya. Depok: PT RajaGrafindo Persada.

Nugraha, Faridani. 2014. Metode Penelitian Kualitatif dalam Penelitian Pendidikan Bahasa. Surakarta.

Priyatni, Endah Tri. 2019. Desain Pembelajaran Bahasa Indonesia dalam Kurikulum 2013. Jakarta Timur: PT Bumi Aksara.

Rochman, Syaiful, dkk. 2018. Analisis High Order Thinking Skill (HOTS) Taksonomi Menganalisis Permasalahan Fisika. Jambi: Universitas Islam Negeri Sulthan Thaha Saifuddin.

Surat Edaran Nomor 14 Tahun 2019 tentang Penyederhanaan Rencana Pelaksanaan Pembelajaran. 2019. Jakarta: Kementerian Pendidikan dan Kebudayaan. 